\title{
INFORMATIZAÇÃO DO MUSEU DE GEOCIÊNCIAS
}

\author{
D.Machadol \\ D.A.Atencio ${ }^{2}$ \\ M.L.Rocha-Campos ${ }^{1}$
}

A informatização do Museu de Geociências visa agilizar os processos de organização, pesquisa, classificação, localização e controle de amostras, aumentando, desta forma, a eficiência no atendimento de solicitações dirigidas ao Museu.

Localizado em instalações do Instituto de Geociências da USP, o Museu de Geociências abriga cerca de $\mathbf{5 0 0 0}$ amostras expostas em vitrines e armários, além de quantidade aproximadamente igual estocada em caixas e gavetas. O Museu é visitado por alunos de primeiro e segundo graus, universitários, colecionadores e pela população em geral. Seu acervo é utilizado para aprendizagem pelos alunos do curso de Geologia e áreas afins, bem como para pesquisas científicas por parte de docentes, pós-graduandos, estagiários e bolsistas de Iniciação Cientffica.

Está sendo desenvolvido um projeto, cujo principal objetivo consiste em atualizar a classificação das amostras de minerais e rochas do Museu, conferindo ao acervo um caráter eminentemente científico e de nivel internacional. Nesta primeira fase do trabalho, tem-se dado ênfase às amostras fora de exposição. Estas amostras estão sendo enquadradas em quatro categorias:

1) destinadạs à exposição: amostras com procedência completa registrada, de espécies ainda não representadas na exposição ou já representadas, mas referentes a localidades diferentes, hábitos diferentes ou de qualidade superior ao material exposto;

2) destinadas a permuta com Museus e colecionadores: amostras com procedência completa registrada, mas já representada na coleção exposta por material da mesma procedência e mesmo hábito, de igual ou superior qualidade;

3) destinadas ao depósito de materiais didáticos, para uso em aulas: amostras de procedência ignorada ou registrada de maneira incompleta, mas de interesse para aprendizagem do reconhecimento de propriedades físicas por parte dos alunos;

4) destinadas a doação para escolas de primeiro e segundo graus ou faculdades: amostras de procedência ignorada ou registrada de maneira incompleta, e sem interesse para

\footnotetext{
${ }^{1}$ Museu, Instituto de Geociências, USP.

${ }^{2}$ Departamento de Mineralogia e Petrologia, Instituto de Geociências, USP.
} 
reconhecimento de propriedades físicas por parte dos alunos, ou disponível no depósito de materiais didáticos em quantidade abundante.

A triagem das amostras passa por diferentes etapas, das quais a primeira é a interpretação do código numérico ou alfa-numérico contido em etiqueta, em geral pintada ou colada na amostra. Este código permite, inicialmente, correlacionar o espécimen com uma das coleções do Museu. Destas, a que contém maior número de exemplares estocados é a Coleção Luiz Paixão. Amostras sem numeração ou com etiquetas corroídas (em geral por insetos), de tal forma que sua leitura é impossível, são automaticamente direcionadas aos destinos 3 ou 4 já especificados.

A seguir, recorre-se a catálogos antigos, que contêm, em geral, a identificação da amostra e, eventualmente, sua procedência completa (cidade, estado, país, algumas vezes também pedreira ou local preciso do afloramento de coleta). Amostras com procedência incompleta (por exemplo, "turmalina de Minas Gerais") são encaminhadas diretamente aos destinos 3 ou 4.

Uma vez que a amostra foi perfeitamente identificada quanto à procedência, verifica-se se os minerais citados no catálogo ou etiqueta correspondem realmente ao material. Este passo é efetuado por observação das propriedades macroscópicas ou microscópicas dos minerais, eventualmente com o auxilio de difratometria de raios $\mathrm{X}$ e análises químicas. Faz-se uso também de trabalhos cientfficos publicados sobre a localidade em questão.

Grande parte dos minerais do Museu acha-se catalogada com nomes antigos em desuso, nomes grafados incorretamente, nomes desnecessários de variedades, nomes desacreditados, nomes regionais, etc. Estes nomes estão sendo trocados por aqueles atualmente aprovados pela Comissão de Novos Minerais e Nomes de Minerais da Associação Mineralógica Internacional, respeitando-se, assim, as regras internacionais de nomenclatura. Os nomes aprovados acham-se relacionados no Mineral Database de Nickel \& Nichols (1993) e no Glossary of Mineral Species de Fleischer \& Mandarino (1991). Para a grafia correta do nome em português, consulta-se o Dicionário de Mineralogia de Branco (1987). Para nomes não encontrados nestas publicações, em geral obsoletos, são consultadas diversas obras antigas ou o trabalho de Clark (1993). As regras básicas de tradução de nomes de minerais do inglês para o português consistem em manter inalterados nomes que homenageiam pessoas (por exemplo, gibbsita) ou referem-se a localidades de coleta (por exemplo, atacamita), a exceção da troca do e final por a. Desta forma, evita-se desrespeitar pessoas e localidades pela omissão de letras ou desfiguração de nomes próprios. No caso de minerais cujo nome deriva de substantivos comuns, fazem-se adaptações necessárias (por exemplo, lanthanite é traduzido para lantanita).

Se for possivel obter o nome correto dos minerais contidos em uma amostra e sua procedência completa, esta é encaminhada aos destinos 1 ou 2. Caso contrário, esta amostra irá para os destinos 3 ou 4. No caso do destino 1, uma ficha para exposição, contendo nome do mineral ou dos minerais, número da amostra, procedência e nome do doador é confeccionada. No caso do destino 2, a amostra é relacionada em uma lista de disponibilidades que será divulgada para Museus e colecionadores.

Um banco de dados, originalmente construído para ser gerenciado pelo programa 
DBase, foi recentemente exportado para o programa TRACKER3. Este banco contém atualmente o registro de 3439 amostras de minerais, todas em exposição, ao qual serão adicionados os dados das novas amostras que estão sendo classificadas nas categorias mencionadas. Cada ficha deste banco de dados contém as seguintes informações: nome do(s) mineral(is), doador, procedência, quantidade de amostras, número da amostra, peso (no caso de gemas), localização no Museu, classe química, tipo de lapidação (no caso de gemas). Além disto, pretende-se incorporar outros campos, como, por exemplo, fórmula química, rocha matriz, dimensões da amostra, principais características visuais dos minerais da amostra (cor, brilho, hábito, formas cristalinas, etc.).

A partir do banco de dados do Museu, podem ser obtidas, com rapidez, listagens de amostras de determinado mineral, localidade, doador, etc. Por exemplo, a Tabela 1 contém todos os registros de amostras do mineral enxofre do Museu.

Programas de computador também tem sido utilizados no Museu de Geociências da USP para atividades rotineiras, como a confecção de folhetos para divulgação do Museu, cartazes, convites para eventos, relatórios anuais, etc.

\section{REFERÊNCIAS BIBLIOGRÁFICAS}

Branco, P.M. (1987) Dicionário de Mineralogia. Porto Alegre, Sagra. 362p.

Clark, A.M. (1993) Hey's Mineral Index. 3rd. Ed. Londres, Chapman \& Hall. 852p.

Fleischer, M. \& Mandarino, J.A. (1991) Glossary of Mineral Species. 6th. Tucson, Mineralogical Record Inc. 256p.

Nickel, E.H. \& Nichols, M.C. (1993) Mineral Database. Aleph/CSIRO. 
Tabela 1 - Amostras de enxofre do Museu de Geociências da USP.

\begin{tabular}{|c|c|c|c|c|}
\hline Nome: & Doador: & Local: & N amost: & Classe: \\
\hline ENXOFRE & $\begin{array}{l}\text { CALTANISSE } \\
\text { TTA, } \\
\text { ITÁLIA }\end{array}$ & 123 & SEMI-METAIS & \\
\hline ENXOFRE & $\begin{array}{l}\text { SICÍLIA, } \\
\text { ITÁLIA }\end{array}$ & 123 & SEMI-METAIS & \\
\hline ENXOFRE & $\begin{array}{l}\text { MARCO } \\
\text { TADEU } \\
\text { SZANKOWSKI }\end{array}$ & ITÁLIA & 123 & SEMI-METAIS \\
\hline ENXOFRE & $\begin{array}{l}\text { ARAUJO } \\
\text { FERRAZ }\end{array}$ & ACARI, RN & 123 & SEMI-METAIS \\
\hline ENXOFRE & $\begin{array}{l}\text { ARAUJO } \\
\text { FERRAZ } \\
\text { ITÁLIA }\end{array}$ & $\begin{array}{l}\text { GIRGENTI, } \\
\text { SICÍLIA, }\end{array}$ & 123 & SEMI-METAIS \\
\hline ENXOFRE & $\begin{array}{l}\text { ARAUJO } \\
\text { FERRAZ }\end{array}$ & $\begin{array}{l}\text { PERGOLA, } \\
\text { ITÁLIA }\end{array}$ & 123 & SEMI-METAIS \\
\hline ENXOFRE & $\begin{array}{l}\text { DARCY } \\
\text { PEDRO } \\
\text { SVISERO }\end{array}$ & $\begin{array}{l}\text { OLLAGUE, } \\
\text { CHILE }\end{array}$ & 123 & SEMI-METAIS \\
\hline ENXOFRE & $\begin{array}{l}\text { CARLOS L. ESPANHA } \\
\text { SCHNYDER }\end{array}$ & 123 & SEMI-METAIS & \\
\hline ENXOFRE & $\begin{array}{l}\text { ARAUJO } \\
\text { FERRAZ }\end{array}$ & $\begin{array}{l}\text { PERTICORA, } \\
\text { ITÁLIA }\end{array}$ & 123 & SEMI-METAIS \\
\hline
\end{tabular}

